\title{
Developing EFL Learner's Speaking Ability, Accuracy and Fluency
}

\author{
Ali Derakhshan ${ }^{1}$, Atefeh Nadi Khalilii ${ }^{2} \&$ Fatima Beheshti $^{2}$ \\ ${ }^{1}$ Department of English Language and Literature, Golestan University, Gorgan, Iran \\ ${ }^{2}$ Department of English Language Teaching, Gorgan Branch, Islamic Azad University, Gorgan, Iran \\ Correspondence: Ali Derakhshan, Department of English Language and Literature, Golestan University, Gorgan, \\ Iran. E-mail: a.derakhshan@gu.ac.ir
}

Received: March 26, 2016

Accepted: May 20, 2016 Online Published: May 23, 2016

doi:10.5539/ells.v6n2p177

URL: http://dx.doi.org/10.5539/ells.v6n2p177

\begin{abstract}
The significant care and the globalization of English have been caused broad demand for good English-speaking skills in various realms. The evidence manifested that some features of speaking abilities are amenable to instruction in the second or foreign language classroom (Derakhshan, Tahery, \& Mirarab, 2015). In spite of the verified evidence in speaking, there are still debates over English as a Foreign Language (EFL) learners' speaking ability and approaches. Therefore, the present paper aimed to provide readers with interesting materials, empowering activities such as imitation, responsive, intensive extensive performance, transactional dialogue, and interpersonal dialogue to improve their speaking abilities. In addition, the EFL learners can boost their speaking ability by utilizing various instruments such as, role play, videos, flash cards, and graphs. Furthermore, this paper takes into account the significant components and keys to improve speaking competence accurately and fluently. To this goal, language teachers have vital roles in creating appropriate environment in the classroom that encourages both children and adults to firstly take part in classroom conversations and then, facilitate opportunities to keep doing it outside of the classroom. Thus, it is beneficial for both children and adults. Finally, this paper reviews some empirical studies to clarify the effectiveness of various methods and approaches to promote the speaking skill accurately and fluently.
\end{abstract}

Keywords: communication, learner, language learning, communicative competence, speaking competence, accuracy and fluency

\section{Introduction}

The past four decades has witnessed the rapid development of speaking skill in second language learning (Derakhshan et al., 2015). Speaking is a complex skill, which should be taught everywhere, and it is a skill that learners learn better in group (Celce-Murica, 2001).

English is divided into four skills which are as follows: listening, speaking, reading, and writing; therefore, speaking is the second skill and has an important role in communication. Speaking is a part of daily life that everyone should develop in subtle and detailed language. One of the most important factors about languageisthat it deals with social contexts and culture (Schmitt, 2012). Culture is massive which covers all the institutions, the attitudes, and the human made features of a huge group non-homogenous people. Teachers cannot teach everything about culture, but they are able to increase intercultural awareness through parameters: information sources, and activity-types (Cullen \& Sato, 2000).

While young language learners acquire foreign language easier and faster, adults are eager in achieving new language and developing language abilities (Staib, 2008). It seems that adults fail to achieve native like proficiency because of "fossilization"; they have problems with prosodic features like: intonation, stress rhythm, etc. (Renandya, 2002). Opportunities for speaking require much structure and planning. Learners often think that the ability to communicate is to know about grammar, but it is also not at the beginning of nineteenth century that the systematic role of teaching was about grammar and then the first method appeared which was called Grammar Translation Method (Celce-Murica, 2001). It was based on grammar and did not help students' speaking ability. After a long time, the evidence showed that listening and reading can improve speaking skill because reading can affect both fluency and accuracy of expression in their speaking (Celce-Murica, 2001). Learning to speak needs a lot of practice; besides, learners should use short dialogue, and questions and answers. If the learners are children, it is better because they are the most holistic learners for communication 
(Celce-Murica, 2001).

One of the most significant current discussions in speaking is developing speaking proficiency and researchers have investigated problems in all aspects of speaking process (Derakhshan \& Shirmohammadli, 2015). A lot of attention has been paid to speaking skill; however, there are some problems in communicative competences and oral task's goals. The primary goal of the presentreview was to provide readers with the interesting materials, impressive activities, and procedures to improve their speaking ability.

\section{Review of the Related Literature}

\subsection{The Aim of Speaking}

According to Harmer (2001), learners should know "language features" and the ability to process them in communication. If the speaker dominates these language features, will help learners to acquire successful communication goal.

Speaking does not cover just knowing the linguistic feature; linguistic feature of the message expanding oral communication requires more than memorized vocabulary and grammatical comprehension. One of the obstacles of learning speaking is contradiction between class materials and courses, so that most of the teachers do not facilitate situations for real practice in speaking; Besides, the teacher should take into account learners' interest and needs. Learners should take part in oral activities to exchange spontaneously their thought in second language speaking (Derakhshan et al., 2015).

Speaking is the production skill that is included in two main categories: accuracy and fluency. Accuracy consists of using vocabulary, grammar and pronunciation through some activities, fluency take into account "the ability to keep going when speaking spontaneously" (Gower, Philips, \& Walter, 1995). Bygate (1987) identified two elements: production skill and interaction skill. In production skill, speaking ability take place without time limit environment and in interaction skill, there is a negotiation between learners. Both skills help learners to improve their speaking ability easier. Stuart (1989) proposed that learners should plan and adjust their talk; and effective speakers should be proficient by practicing. It shows that speaking is high risking activity that creates anxiety and causes learners worry about losing face.

\subsection{Developing Speaking Skills}

One of the most important goals of teachers is to enable learners to use English for communication. According to many theories, speaking skill can be improved by games, role play, etc. Evidence shows that speaking should incorporate activities in a group work (Oradee, 2012). There are some types of speaking performance that can help students to improve speaking skill (Brown, 2007).

\subsubsection{Imitation}

Students should pay attention to certain vowel sounds and intonations; next they should imitate correctly. Meanwhile learners need to practice an intonation contour or to find exactly certain vowel sound.

\subsubsection{Responsive}

It refers to short replies to teachers. It can be learners to initiated questions or comments. Students should be active in the classroom. They should reply to teachers' questions and comments. They should participate in the classroom. For example:

\section{T: How's it going?}

\section{S: Pretty good!}

\subsubsection{Intensive}

Any speaking performance is planned to practice some phonological or grammatical features of language that can be self-initiated or pair work activity (Brown, 2007).

\subsubsection{Transactional Dialogue}

It is used to convey a message or exchange the information. In addition, it is utilized to elaborate a concept or to manifest the purpose of something. Learners should participate in conversation (Brown, 2007). For example:

\section{$\mathrm{T}$ : What is the main idea in this essay?}

\section{$\mathrm{S}$ : The USA should have more power.}

$\mathrm{T}$ : What do you mean?

S: Well, for example the USA should have the power to destroy the others countries. 


\subsubsection{Interpersonal Dialogue}

It is regarded as maintaining social relationships not for transmission of facts and information involves factors like: casual register, colloquial language, slang, ellipsis, sarcasm and a covert "agenda" (Brown, 2007). For example:

\section{Carol: Hi, Tom, How's it going?}

Tom: Oh, not bad.

Carol: Not a great weekend, huh?

Tom: Well, I'm really miffed about last week.

\subsubsection{Extensive}

It refers to students at intermediate to advanced levels that are asked to provide extensive monologues in the form of oral reports, summaries or short speech (Brown, 2007). In order to improve second language skills, learners should practice regularly. First learners should expand their general vocabulary and then they can improve their domain of vocabulary by listening from simple sentences to complex sentences. Meanwhile they can increase their knowledge by reading short story and sometimes memorizing some important parts of it (Chastain, 1988). When you read a book, story and magazine aloud, it can help you more. When you practice, your fluency would be better, too (Celce-Murica, 2001). According to Hedge the term fluency has two meanings:

The first, which is the ability to link unit of speech together with facility and without strain or in opportunities slowness undue hesitation and purpose a second, more holistic sense of fluency that of natural language use which is likely to take place when speaking activities focus on meaning and its negotiation when speaking strategies are used and when over correction is minimized (as cited in Celce-Murica, 2001, p. 104). We should encourage students to take responsibility for their own learning; they should encounter with simple procedures. Another important factor is that the learners should participate in conversation by setting up a group (Celce-Murica, 2001). The conversation between students and the teacher should be based on classroom observation data (Wenli, 2005). Some teachers have problems with students that do not participate in classroom and are always silent like Chinese and Japanese students. Teachers should provide students facilities to participate in group work, for example: use pictures, role play, etc. (Wenli, 2005). Some studies show that teachers should prepare suitable environment for students to facilitate learning process (Flower \& Miller, as cited in Wenli, 2005, p. 48).

Learners can boost speaking fluency through "partner taping". Partner taping encourages students to stay in English while taping improves greater fluency and achieves extra practice outside of class and develop students' responsibility for their learning. It also suggests simple practical "low tech" method of getting to improve more fluency in a foreign language and take responsibility for their language practice. It is for teacher to apply additional work in order to expand students' English speaking ability (Kluge \& Taylor, 1999; Schneider, 1993, 1997).

\subsection{How Can Teachers ImproveStudents'Speaking Skill?}

Teachers should use a lot of English speaking activities to motivate learners to study and speak in English, and they should increase learning classroom environment (Oradee, 2012). Teachers can use a funny discussion and ask students to talk about their best moments that they ever had. Students' participation in discussion causes other students to actively take part in negotiation; therefore, students become surprised about their ability and intelligence (Celce-Murica, 2001). Some students have a lack of desire to speak because of their shyness and low confidence, but there is no appropriate solution about how teachers can overcome this problem (Chastain, 1988). Evidence shows that these learners should start with short answers, and short sentences, but it may be time-consuming (Chastain, 1988).

\subsubsection{Role-play}

According to Tatayama (1998), role play is a part of activity derived by various approaches to languages. He also mentioned that it is vital to improve learners' comprehension and production system and their ability would be cooperate socio-pragmatic and pragma-linguistic knowledge in interaction. Role-play is one of the methods that enable learners to improve a range of real life spoken language in the classroom (Cook, 2001). For example, a teacher chooses a conversation from a book and after repeating aloud with students, teacher asked some students to be volunteers in role-play. This activity can help students to overcome their shyness, fears and anxiety. Learners can listen and practice phrases that are used in speech acts (Celce-Murica, 2001). 


\subsubsection{Videos}

Çakır (2006) found that video materials have improved due to increasing the quality of speaking ability. According to an investigation by Rice \& Woodsmall (1988), the video markedly raise learners' lexical grammar. The effectiveness of video depends on students' age and interest in specific context (Silverman \& Hines, 2009).

\subsubsection{Flashcards}

As highlighted by Palka (1988) flashcards have significant effect not only for learning vocabulary but also for learning sentences structures, tenses and phrasal verbs. Meanwhile, Brown (2000) claims that learners usually cope with new words by flash cards and most learners try to use them to review it afterwards.

\subsubsection{Graphs}

Graphs "serve as representation of real observation and as analytic tools for detecting under lying patterns which in turn inform the observer and the learner about phenomena (the target) under investigation" (Leinhardt, Zaslavsky, \& Stein, 1990, p. 20). Traditional views consider graphing as intelligence manifested in students' minds (Lynch, 1992).

Another way to improve learners' presentation is to utilizevideos, graphs and flash cards (Pesce, 2013). Also using flash cards has appropriate effects on young learners (Kayi, 2006). Besides, using pictures has vital rules in learning grammars on learner speaking ability (Ghapanchi \& Sabouri, 2013). There are a lot of chants for children and adults, make learners proficient in vocabulary and pronunciation. They tell story and draw some pictures for learner and tell them "now you do it" (Celce-Murica, 2001).

The other technique is interview. The significant advantage of interviews is their flexibility. They can be long or short and useful for learners from beginning level to advanced level; with high aptitude and low aptitude learners. They can be considered as additional oral activities or subsequent writing task.

Another important factor is pronunciation. Learners have problems to pronounce words fluently with native like pronunciation because of prosodic features: like intonation, stress and other phonological nuances (Richards \& Renandya, 2002). Another factor that Celce-Murica (2001) mentioned is intonation. Intonation can help learners analyze and generalize the sentences to notice the stress timed. Moreover, Internet can provide broad resources for learners and even teachers. There are a lot of sites and CDs that can help learners to pronounce like native learners (Nunan, 1991).

Knowing grammatical and semantic rules is not sufficient instruments for speaking. Learners must be familiar with the knowledge of how native speakers use the language in the context of well-organized interpersonal exchange, in which many factors interact. Thus, it is difficult for EFL learners, especially adults, to speak the target language fluently and appropriately (Richards \& Renandya, 2002). Wong (2006) postulates that speaking competence deals with speaking accuracy and fluency. Speaking accuracy demonstrates "the extent to which the language produced conforms to language norms" (Yuan \& Ellis, 2003, p. 2) under which the appropriate use of pronunciation, vocabulary, and grammar are subsumed. Speaking fluency pertains to the ability to produce the spoken language "without undue pausing or hesitation" (Skehan, 1996, p. 22). Speaking can be deemed as an indispensable tool for language teaching and learning since it can "facilitate language acquisition and development" (Goh, 2007, p. 1), and it can be fruitful to learner's academic accomplishment and professional success (Saunders \& O'Brien, 2006).

\section{Components Underlying Speaking Effectiveness}

Hymes (1971) believes that L2 learners are required to know both the linguistic knowledge and the culturally appropriate ways to interact with others in diverse situations. According to Hymes, communicative competence is composed of grammatical, psycholinguistic, sociolinguistic, and language components. Communicative competence went under some other modifications by Canale \& Swain (1980) who posit that communicative competence encompasses grammatical competence, discourse competence, sociolinguistic competence, and strategic competence which per se demonstrate the use of linguistic system and the functional aspects of communication.

\subsection{Grammatical Competence}

Scarcella \& Oxford (1992) propound that grammatical competence is an overarching component that consists of knowledge of grammar, vocabulary, and sounds of letters and syllables, pronunciation of words, intonation, and stress. To understand meaning, EFL learners need to have enough knowledge of words and sentences: that is, they must figure out how words are broken into different sounds, and how sentences are stressed in particular ways. So, grammatical competence helps speakers to use and understand English language structures accurately 
and immediately, which facilitates their fluency (Richards \& Renandya, 2002).

\subsection{Discourse Competence}

EFL learners should develop discourse competence through international relationships. The rules of cohesion and coherence should be applied in each discourse, whether formal or informal to hold the communication together in a meaningful way (Richards \& Renandya, 2002). In order to communicate well, speakers are required to perceive and process stretches of discourse and to formulate representations of meaning from referents in both previous sentences and following sentences (Richards \& Renandya, 2002). Thus, effective speakers need to gain a large repertoire of structures and discourse makers to express ideas, indicate relationships of time, and show cause, contrast, and emphasis (Scarcella \& Oxford, 1992).

\subsection{Sociolinguistic Competence}

To know the knowledge of language is not enough for EFL learners to speak effectively and appropriately. They should be familiar with the culture of the native speakers to enable to use target language which is socially and culturally acceptable by native users. To achieve this goal, it is imperative to figure out the sociolinguistic side of language which enables learners distinguish appropriate comments, how to ask questions during interaction, and how to respond nonverbally according to the aim of the talk (Richards \& Renandya, 2002, p. 2012). Therefore, as Brown (1994) asserts, adult second language learners need to learn stylistic adaptability so as to be able to encode and decode the discourse around them appropriately.

\subsection{Strategic Competence}

Strategic competence means the ability of appropriate use of language. It can refer to the ability to know when and how to initiate, maintain, and terminate the conversation and how to clear up communication breakdowns and comprehension problems (Richards \& Renandya, 2002). In addition, strategic competence is "the way learners manipulate language in order to meet communicative goals" (Brown, 1994, p. 228). Further, it can be the ability to make up for faulty knowledge of linguistic, sociolinguistic, and discourse rules (Berns, 1990).

\section{Factors Influencing Learner's Speaking Competence}

\subsection{Cognitive Factors}

According to Levelt (1989), the speaking processes include conceptualization, formation, and articulation. Conceptualization pertains to what information can be opted to express the meaning. Formulation refers to the ability of the speaker to decide what proper words to use in appropriate grammatical structures. And articulation requires the speaker to articulate the speech with his articulatory organs. Since all the three processes happen at concurrently, it is contingent that learners make mistakes especially in face-to-face communication. Therefore, Hughes (2002) argues that their speaking is filled with hesitation, false-starts, grammatical inaccuracies, and as well as limited vocabulary. Besides, McLaughlin \& Heredia (1996) assert that since human's mind is a "limited capacity processor" (p. 214), it is not easy to concentrate on everything simultaneously. Putting too much emphasis on accuracy may cause the lack of fluency, and too much stress on fluency may lead to the lack of accuracy (Skehan \& Foster, 1999).

\subsection{Linguistic Factors}

The appropriate use of language forms is important for learner's oral proficiency (Saunders \& O'Brien, 2006). Linguistic factors include several features like pronunciation, grammar, and vocabulary. It is believed that pronunciation plays avital role in intelligibility (Goh, 2007). In addition, grammar acts as an essential role in learning the structure of English, but the implementation of correct use of grammar in one's speech is more important than learning the accurate use of grammar. Larsen-Freeman (2001) cites that it seems difficult for EFL learners to transfer the appropriate grammar to their speaking. Vocabulary is essential for EFL learners since it is the building block of every language. If the receptive vocabulary is rather limited, learners can seldom put the "receptive vocabulary knowledge into productive use" (Nation, 2001, p. 129); therefore, it is necessary for EFL learners to keep a lot of vocabulary in their long-term memory. Furthermore, the ability to pick up words from one's mind may cover the speaking fluency (Carter, 2001; Levelt, 1989).

\subsection{Affective Factors}

It is assumed that anxiety and self-restriction have an influence on learner's oral proficiency. Anxiety is the affective factor that most dominantly blocks the learning process (Arnold \& Brown, 1999). Worrying about being "wrong, stupid, or incomprehensible" (Brown, 2001, p. 269) completely influences learners' speaking performance. Most of EFL learners are stressed out in class (Liu, 2006) especially when they are called on to speak in class without any preparation. Shumin (2002) accentuates that if learners are too much nervous, they 
become tongue-tied or lost for wordswhich per see completely affects their achievement in foreign language classroom (Zhang \& Jia, 2006). Because the ability to take risks is regarded as an essence for "successful learning of a second language" (Brown, 2007, p. 160), EFL learners need to be encouraged to speak bravely so as to promote their speaking competence gradually since motivation is believed to be the most significant factor that educators can target in order to facilitate learning (Olson, 1997).

\section{Interactions: Keys to Improve EFL Learners' Speaking Abilities}

Spoken language usually has two functions: interactional and transactional. The essential goal of the former is to keep social relationships, but that of the latter is to pass information and ideas. Because much of our daily communication is interactional, being able to interact is imperative. Thus, language instructors should facilitate learners' with meaningful communicative situations about proper topics by applying leaner-learner interaction as the key to teach communicative language (Richards \& Renandya, 2002). Communication drives essentially from interaction (Rivers, 1987, p. 30). Classroom communication includes meaning-focused activity and learners can learn how to listen and talk to others, how to negotiate meaning in shared context both verbally and non-verbally with the help of teacher (Richards \& Renandya, 2002). Nunan (1989) expounds that in order to design activities; teachers need to take into consideration the integration of four language skills as they interact with each other in natural behavior, because in real life situations as in the classroom, most tasks of any complexity involve more than one macro skill.

\section{Empirical Studies}

Some studies have been done to manifest significance of developing speaking abilities. For example, Farooqui (2007) postulates that due to the extreme demand for good and native-like English-speaking skills especially in the job market, Bangladesh puts a great emphasis onthe teaching of English speaking skills. The evidence shows that private universities focus on improving English skills. However, students of public and private universities have an equal level of proficiency when they begin. When they graduate, the students of private universities have achieved a higher level of proficiency in English. Affiliated study examines how these private universities assist the students to improve English language skills through observation, document analysis and a series of interviews with teachers who are teaching English language in these private universities. He investigated teacher's understanding of the students' difficulties during speaking English and the factors that help these students to improve their speaking skills.

Alternatively, Razmjoo \& Ghasemi Ardekani (2011) tried to propose a model of speaking proficiency on the use of strategies. Therefore, their study was designed to have two main breakdowns such as qualitative and quantitative. Regarding this, 30 EFL learners' perspectives were analyzed, and then according to the received replies, a 21-item speaking strategy questionnaire was developed and given to 210 EFL learners. To choose a subset of common replies and put off the spare ones, factor analysis was used, and then 7 elements were elicited. These elements, divided according to the offline/online concepts or the time of speaking, included a model representing speaking strategies. Consequently, their study manifested that EFL learners' gender and level of proficiency do not influence their speaking strategy use.

Similarly, Nazara (2011) examined students' perceptions on EFL speaking skill development of the English Teaching Study program of FKIPUKI Jakarta. The results revealed that all students considered speaking significant, and they were amenable to evaluate the requirements to boost it. However, they provided wonderful materials, promoting activities, and suitable situation to practice speaking, they asserted to have longer time to practice. Moreover, some students were reluctant to speak because of their stress of lecturers, basting, and classmates' mocking. The paper concludes by proposing the need to make a friendly and facilitative climate in the classroom.

Khan \& Arshad (2012) have highlighted the need for knowing English as a subject and a language. They believe that learners require to listen to English with correct pronunciation and do kind of exercises and take part in debate races. They analyzed 20 male students and 20 female students. They concluded that it is necessary to teach English as a subject. English as a language is not given chance to learners to improve their speaking ability. Teachers should be more responsible by having expert knowledge and abilities to develop second language ability, more emphasize on the quality of books, more given time to speaking and more phonetic exercise of learners. Teachers should also provide friendly environment for students and improve boldness and self-assurance in learners for asking questions.

Kavaliauskienè (2013) investigated students'perspectives to improve speaking ability in English classes for special purposes. He mentioned speaking is aproductive ability because it is hard to master. Therefore, he reported the questionnaires on learners' attitude to find speaking activities in the classroom. The conclusion 
showed the learners' responses acquired in three academic years of 2010, 2011, and 2012. It was found that learners' attitudes were different and learners were more reluctant to short talks and discussions. The short talks are obligatory and graded in ESP classes. Learners' discussion and spontaneous speakers have not been graded because, self-assured learners take part in activities but passive learners fail to contribute.

According to the study conducted by Askari \& Langroudi (2014), the effectiveness of Ur's model in developing Iranian EFL learners' fluency and accuracy in speaking was investigated. To do so, 60 Iranian EFL learners were chosen according to their performance on Oxford Placement Test (OPT). The participants were randomly set aside to two unbiased groups of Ur model and control. The groups received speaking instruction according to the Ur's 5-component model and standard tactics of speaking instruction. Statistical results of t-test manifested that Ur's model had an effective role in achieving both fluency and accuracy of EFL learners. The outcomes of the present study supported a model of empirical evidence that is found by Ur (2009). Ur's model directed attention to both mechanical and communicative practices to guide learners from accuracy to fluency.

Wang (2014) investigated Chinese EFL learners who may have some problems in speaking English fluently and accurately, because their speaking competence maybe affected by cognitive, linguistic and emotional factors. With respect to this, the research was conducted by Development of Education of Sichuan province. The purpose of the research was to achieve learners' oral proficiency first through evaluating three vital models of teaching English speaking, and then suggesting a four-step educational method through four stages: pre-speaking, while-speaking, post-speaking and extension activity. Before speaking, students need to be empowered enough in knowledge, vocabulary and strategies to decrease their fear and stress. While speaking, learners should have sufficient time and space to promote their fluency, with overall attention to delineate their meanings. After speaking, learners need to be given opportunities to figure out the appropriate use of language to develop their speaking accuracy. Finally, extension practice is eloquent to boost learners' language use because task repetition assists learners to improve fluent and accurate spoken English.

Khosravani \& Khosravani (2014) proposed that improving speaking ability has been one of the major interesting research subjects due to the effect of reading short stories on EFL learners speaking skill. Therefore, the researchers conducted the study on 172 teachers. In these classes, learners read the stories, summarized them and then they answered the classmates' questions for the next session. The result revealed that it can help learners to boost their independent English learning and improve their speaking skill by short stories. This study will be valuable for teachers who are looking for ways of developing speaking and listening of their learners.

Mohammadi, Gorjian, \& Pzhakh (2014) have demonstrated that the possible impact of classroom structure on the speaking skills of Iranian EFL learners. They studied learners' performance in aggressive, cooperative or individualistic environment. For this purpose, they selected 160 male pre-university students in Mathematics. They selected 120 participants randomly, who were divided into four groups. All experimental groups were taught English in General Purpose (EGP), but control group practiced in the classroom environment. The findings provided evidence that experimental groups were better than the control group; it means classroom structure has special impact on speaking skill. The result showed that there was not any special contrast between aggressive, cooperative or individualistic.

Azadi, Aliakbariand Azizifar (2015) posited that one of the most significant discussions on speaking is to transport the messages to the others, and it is necessary to have the ability to communicate adequately. Classroom interaction has a vital role in improving speaking ability. For this purpose, they considered the effect of teaching speaking strategies and learners' gender on developing speaking skill. They studied 30 intermediate language learners and used posttest and pretest design to analyze the research questions. The results showed that the classroom interaction is the way of improving the learners' speaking skill and gender has no effect on their speaking performance. Organizing the classroom so that it dedicates most of the class time to students interaction and promoting conversation between them can be a good way of encouraging classroom interaction.

\section{Conclusion}

In conclusion, one of the most important components of communication is speaking. In EFL contexts, it is an imperative factor which requires special attention and instruction. Thus, it is the responsibility of EFLteachers of EFL to exactly investigate the factors, conditions, and components that form the basis of effective speaking. Effective instructions inferred from the careful analysis of this area, together with sufficient language input and speech-promotion activities, will gradually help learners speak English fluently and appropriately (Richards \& Renandya, 2002). The present paper deals with factors and issues with which have great influence on speaking ability, accuracy and fluency. Although a lot of studies have been done in this area, we feel the need for further research to provide some solutions for teachers to apply more effective methods and procedures in their teaching. 
Effective methods include using role-play, pictures, flash cards, graphs, chants and interview that can improve learners' pronunciation, grammar, every day speech and real word activities. Further, it can eclipse both adults and children to improve their speaking along with accuracy and fluency, so that they can reach their goal that is speaking English fluently and appropriately. Moreover the previous factors have a great impact on developing positive attitudes factors toward learning English as a foreign language. English teachers should consider the previous factors and principals according to their students' needs, interest and teaching context. Finally it is worth mentioning that empowering positive perspective toward EFL learning is dynamic performance (Tsiplakides \& Keramida, 2010).

\section{References}

Arnold, J., \& Brown, H. D. (1999). A map of the terrain. In J. Arnold (Ed.), Affective method in language leaning (pp. 1-24). Cambridge: Cambridge University Press.

Askari, K., \& Langroudi, J. (2014). The effectiveness of Ur model in developing Iranian EFL learners' fluency and accuracy in speaking. Applied Linguistic and LanguageResearch, 1(1), 75-86.

Azadi, S., Aliakbari, M., \& Azizifar, A. (2015). The role of classroom interaction on improvement of speaking among Iranian EFL learners. International Journal of Language Learning and Applied Linguistics World (IJLLALW), 8(1), 126-135.

Berns, M. (1990). Contexts of competence: Socialand cultural considerations in communicative language teaching. New York: Plenum Press. http://dx.doi.org/10.1007/978-1-4757-9838-8

Brown, H. D. (1994). Principle of language learning and teaching. Englewood Cliffs, NJ: Pentice Hall.

Brown, H. D. (2000). Principles of language learning and teaching (4th ed.). New York: London.

Brown, H. D. (2001). Teaching by principles: An interactive approach to language pedagogy (2nd ed.). White Plains, NY: Longman.

Brown, H. D. (2007). Principle of language learning and teaching. White Plains, NY: Pearson Longman.

Bygate, M. (1987). Speaking: The Cambridge guide to teaching English to speakers of other Language. Cambridge: Cambridge University Press.

Çakır, I. (2006). The use of video as an audio-visual material in foreign language teaching classroom. The Turkish Online Journal of Educational Technology, 5(4), 67-72.

Canale, M., \& Swain, M. (1980). Theoretical bases of communicative approaches to second language teaching and testing. Applied Linguistics, 1(1), 1-47. http://dx.doi.org/10.1093/applin/1.1.1

Carter, R. N. (2001). Vocabulary and language teaching. London: Longman.

Celce-Murica, M. (2001).Teaching English as a second language or foreign language (2nd ed.). New York: Newbury House.

Chastain, K. (1988). Developing second language skills: Theory and practice. San Diego: Rand McNally College Publisher.

Cook, V. (2001). Second language learning and language teaching (3rd ed.). Oxford: Oxford University Press.

Cullen, B., \& Sato, K. (2000). Practical techniques for teaching culture in the EFL classroom. Retrieved from http://iteslj.Org/Techniques/Cullen-Culture.html

Derakhshan, A., \& Shirmohammadi, M. (2015). The difficulties of teaching English language: The relationship between research and teaching. International Journal of Linguistics, 7(1), 102-110. http://dx.doi.org/10.5296/ijl.v7i1.6648

Derakhshan, A., Tahery, F., \& Mirarab, N. (2015). Helping adult and young learner to communicate in speaking classes with confidence. Mediterranean Journal of Social Science, 6(2), 520-525. http://dx.doi.org/10.5901/mjss.2015.v6n2p520

Evans, J. (1992). Language sample collection and analysis: interview compared to free playassessment contexts. Journal of Speech \& Hearing Research, 35(2), 343-353. http://dx.doi.org/10.1044/jshr.3502.343

Farooqui, S. (2007). Developing speaking skills of adult learners in private universities in Bangladesh: Problems and solutions. Australian Journal of Adult Learning, 47(1), 95-110.

Ghapanchi, Z., \& Sabori, F. (2013). The implicit instruction of grammar via picture: A technique to improve writing and speaking abilitiesof Iranian elementary EFL learners. Iranian EFL Journal, 2(9), 208-221. 
Goh, C. C. M. (2007). Teaching speaking in the language classroom. Singapore: SEAMEO Regional Language Centre.

Gower, R., Phillips, D., \& Walters, S. (1995). Teaching practice handbook. Oxford: MacMillan Education.

Harmer, J. (2001). The practice of English language teaching (3rd ed). London: Longman.

Hughes, R. (2002). Teaching and researching speaking. Edinburgh: Pearson Education.

Hymes, D. (1971). On communicative competence. Philadelphia: University of Pennsylvania Press.

Kavaliauskienė, G. (2013). Ongoing research in to speaking skill. English for Specific Purposes World, 38(14), $1-9$.

Kayi, H. (2006). Teaching speaking: Activities to promote speaking in a second language. TESOL, 11(12), 1-6.

Khan, N., \& Arshad, A. (2010). Improving the speaking ability in English: The students' perspective. Procedia Social and Behavioral Sciences, 2(2), 3575-3579. http://dx.doi.org/10.1016/j.sbspro.2010.03.554

Khosravani, M., \& Khosravani, M. (2014). Fostering EFL learners' speaking and listening skill via oral activities of reading short stories. International Journal of Language Learning and Applied Linguistics Worlds (IJLLALW), 5(1), 329-337.

Kluge, D., \& Taylor, M. (1999). In my life: A conversation workbook. Nagoya: KinjoGakuin University.

Larsen-Freeman, D. (2001). Grammar. In R. Carter \& D. Nunan (Eds.), The Cambridge guide to teaching English to speakers of otherlanguages (pp. 34-41). Cambridge: Cambridge University Press. http://dx.doi.org/10.1017/CBO9780511667206.006

Leinhardt, G., Zaslavsky, O., \& Stein, M. K. (1990). Functions, graphs, and graphing: Tasks, learning, and teaching. Review of Educational Research, 60(1), 1-65. http://dx.doi.org/10.3102/00346543060001001

Levelt, W. J. M. (1989). Speaking: Form intention to articulation. Cambridge: MIT Press.

Liu, M. H. (2006). Anxiety in Chinese EFL students at different proficiency levels. System, 34(1), 301-316. http://dx.doi.org/10.1016/j.system.2006.04.004

Lynch, M. (1992). Extending Wittgenstein: The pivotal move from epistemology to the sociology of science. In A. Pickering (Ed.), Science as practice and culture (pp. 215-300). Chicago, IL: University of Chicago Press.

McLaughlin, B., \& Heredia, R. (1996). Information-processing approaches to research on second language acquisition and use. In W. C. Ritchie \& T. K. Bhatia (Eds.), Handbook of second language acquisition (pp. 213-228). San Diego: Academic Press. http://dx.doi.org/10.1016/b978-012589042-7/50009-8

Mohammadi, M., Gorjian, B., \& Pazhakh, A. (2014). The effect of classroom structure on speaking skills of Iranian learners: A comparative study. International Journal of Language Learning and Applied Linguistics World (IJLLALW), 5(1), 472-487.

Nation, L. S. P. (2001). Learning vocabulary in another language. Cambridge: Cambridge University Press. http://dx.doi.org/10.1017/CBO9781139524759

Nazara, S. (2011). Students' perception on EFL speaking skill development. Journal of English Teaching, 1(1), 28-43.

Nunan, D. C. (1989). Designing tasks for the communicative classroom. Cambridge: Cambridge University Press.

Nunan, K. (1991). Theories of communication. Retrieved from http://lali24saly.wikispace.com/speaking/theory

Olson, G. (1997). Motivation, motivation, motivation-secondary school educator. Retrieved from http://934/http://7-12educators

Oradee, Th. (2012). Developing speaking skills using three communicative activities (discussion, problem-solving, and role- play). International Journal of Social Science and Humanity, 2(6), 532- 533.

Palka, E. (1988). Using cards to revise and practice language items. (ERIC Document Reproduction Service No. ED 302093).

Pesce, C. (2013). Try these 7 sure-fire ways to boost student confidence. Retrieved from http://www.lessonpath.com/learn.i/ideas/for-teaching

Razmjoo, S. A., \& Ghasemi, A. S. (2011). A model of speaking strategies for EFL learners. The Journal of 
Teaching Language Skills (JTLS), 3(3), 116-140.

Renandya, W. A. (2002). Methodology in language teaching: An anthology of current practice. Cambridge: Cambridge University Press.

Rice, M., \& Woodsmall, L. (1988). Lessons from television: Children's world learning when viewing. Child Development, 59(1), 420-429. http://dx.doi.org/10.2307/1130321

Richards, J. C., \& Renandya, W. A. (2002). Methodology in language teaching. New York: Cambridge University Press. http://dx.doi.org/10.1017/CBO9780511667190

Rivers, W. M. (1987). Interactive language teaching. Cambridge: Cambridge University Press.

Saunders, W. M., \& O’Biren, G. (2006). Oral language. In F. Genesee, K. Lindholm-Leary, W. M. Saunders, \& D. Christian (Eds.), Educating English language learners: A synthesis of research evidence (pp. 14-45). Cambridge: Cambridge University Press.

Scarcella, R. C., \& Oxford, R .L. (1992). The tapestry of language learning: The individual in the communicative classroom. Boston, MA: Heinle \& Heinle.

Schmitt, R. (2012). Applied linguistic. In A. Burns \& B. Seidhofer (Eds.), Speaking and pronunciation (pp.197-199). London: Great Britain press.

Schneider, P. (1993). Developing fluency with pair taping. JALT Journal, 15(1), 55-62.

Schneider, P. (1997). Using pair taping. Retrieved from http://iteslj.org/Techniques/Schneider-PairTaping.html

Shumin, K. (2002). Factors to consider: Developing adult EFL student speaking abilities. In J. C. Richards \& W. A. Renandya (Eds.), Methodologyin language teaching: An anthology of current practice (pp. 204-211). Cambridge: Cambridge University Press. http://dx.doi.org/10.1017/CBO9780511667190.028

Silverman, R., \& Hines, S. (2009). The effects of multimedia-enhanced instruction on the vocabulary of English-language learners and non-English-language learners in pre-kindergarten through second grade. Journal of Educational Psychology, 101(2), 305-314. http://dx.doi.org/10.1037/a0014217

Skehan, P. (1996). Second language acquisition research and task-based instruction. In J. Willis \& D. Willis (Eds.), Challenge and change in language teaching (pp.17-30). Oxford: Heinemann.

Skehan, P., \& Foster, P. (1999). The influence of task structure and processing conditions on narrative retellings. Language Learning, 49(1), 93-120. http://dx.doi.org/10.1111/1467-9922.00071

Staib, K. (2008). 10 secrets to motivating teenagers. Retrieved from http://www.workhappynow.com

Stuart, C. (1989). Be an effective speaker. Chicago: NTC/Contemporary Publishing Company.

Tatayama, Y. (1998). Explicit and implicit teaching of pragmatic routines: Japanese Sumimasen. In K. R. Rose \& G. Kasper (Eds.), Pragmatics in language teaching. Cambridge: Cambridge University Press.

Tsiplakides, L., \& Keramida, A. (2010). Promoting positive attitudes ESL/ EFL classes. The Internet TESL Journal, 16(1). Retrieved from https://snurprima.wordpress.com/page/2/

Wang, Z. (2014). Developing accuracy and fluency in spoken English of Chinese EFL learners. English Language Teaching, 7(2), 110-118. http://dx.doi.org/10.5539/elt.v7n2p110

Wenli, T. (2005). Improving speaking skills through instruction in oral classroom participation. System, 38(1), 48-56.

Wong, C. (1984). Social cultural factors counteract the instructional efforts of teaching through English in Hong-Kong (Unpublished doctoral dissertation). University of Washington: Seattle.

Yuan, F., \& Ellis, R. (2003). The effects of pre-task planning and on-line planning on fluency, complexity and accuracy in L2 monologic oral production. Applied Linguistics, 24(1), 1-27. http://dx.doi.org/10.1093/applin/24.1.1

Zhang, Y. L., \& Jia, G. Z. (2006). Anxiety in foreign language classroom. CELEA Journal, 29(6), 96-103.

\section{Copyrights}

Copyright for this article is retained by the author(s), with first publication rights granted to the journal.

This is an open-access article distributed under the terms and conditions of the Creative Commons Attribution license (http://creativecommons.org/licenses/by/3.0/). 